Studies by the U.S. Geological Survey in Alaska, Volume 15

\title{
U-Pb Geochronology and Tectonic Implications of a Silurian Ash in the Farewell Terrane, Alaska
}

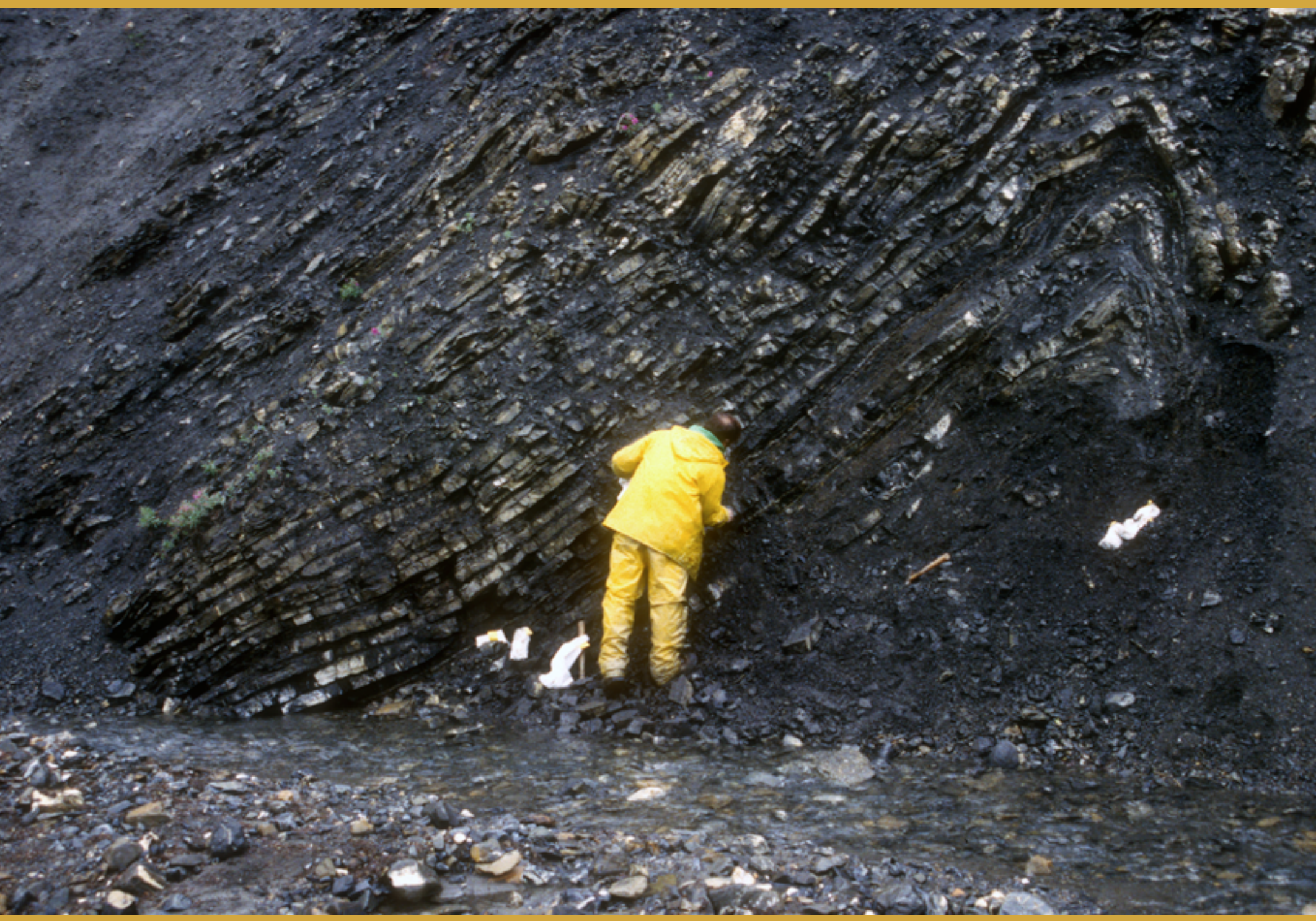

Professional Paper 1814-F

U.S. Department of the Interior

U.S. Geological Survey 


\section{FRONT COVER}

Section of calcareous radiolarite, subordinate graywacke turbidites, and thin ash layers, Mount McKinley quadrangle, Alaska (location 9 in text). U.S. Geological Survey photograph by Julie Dumoulin. 
Studies by the U.S. Geological Survey in Alaska, Volume 15

\section{$\mathrm{U}-\mathrm{Pb}$ Geochronology and Tectonic Implications of a Silurian Ash in the Farewell Terrane, Alaska}

By Dwight C. Bradley, Julie A. Dumoulin, and Dan B. Bradley

Professional Paper 1814-F 


\title{
U.S. Department of the Interior \\ RYAN K. ZINKE, Secretary
}

\author{
U.S. Geological Survey \\ James F. Reilly II, Director
}

U.S. Geological Survey, Reston, Virginia: 2018

For more information on the USGS - the Federal source for science about the Earth, its natural and living resources, natural hazards, and the environment - visit http://www.usgs.gov/ or call 1-888-ASK-USGS (1-888-275-8747).

For an overview of USGS information products, including maps, imagery, and publications, visit http://www.usgs.gov/pubprod/.

Any use of trade, firm, or product names is for descriptive purposes only and does not imply endorsement by the U.S. Government.

Although this information product, for the most part, is in the public domain, it also may contain copyrighted materials as noted in the text. Permission to reproduce copyrighted items must be secured from the copyright owner.

Suggested citation:

Bradley, D.C., Dumoulin, J.A., and Bradley, D.B., 2018, U-Pb geochronology and tectonic implications of a Silurian ash in the Farewell terrane, Alaska, in Dumoulin, J.A., ed., Studies by the U.S. Geological Survey in Alaska, vol. 15: U.S. Geological Survey Professional Paper 1814-F, 13 p., https://doi.org/10.3133/pp1814F. 


\section{Contents}

Abstract
Introduction
Geologic Setting
U-Pb Geochronology
Discussion
$\quad$ Passive Margin Evolution
Age Overlap Between the Dated Ash and a Widespread Detrital-Zircon Age Maximum
Acknowlications for Plate Reconstructions
References Cited

\section{Figures}

1. Generalized tectonic map of Alaska showing the Farewell terrane and selected other

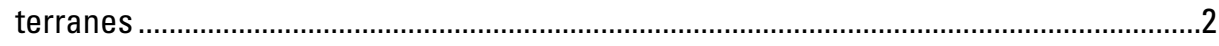

2. Geologic map of part of the Mount McKinley quadrangle, Alaska...........................................3

3. Farewell subterrane nomenclature showing approximate position of the dated

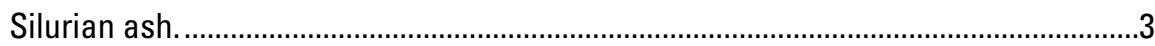

4. Detailed measured section from the ash-bearing succession at location 9 ...........................4

5. Cathodoluminescence images of the dated zircons from sample 96AD8F at location 9 ...........4

6. Plot showing ${ }^{238} \mathrm{U} / 206 \mathrm{~Pb}$ zircon age results for sample $96 \mathrm{AD} 8 \mathrm{~F}$............................................20

7. Detrital zircon age distributions for Silurian and Devonian rock units in western, northern, and eastern North America that have prominent age peaks at $440-420 \mathrm{Ma}$..................8

8. Map of North America showing locations of terranes and rock units mentioned in text

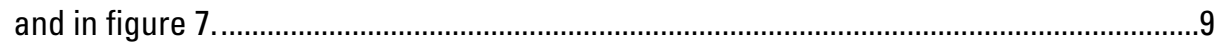

9. Schematic tectonic reconstruction at about $433 \mathrm{Ma}$ (approximately equivalent to the Llandovery-Wenlock boundary), modified from the extrusion model of Colpron and Nelson $(2009,2011)$ to better account for evidence from the Farewell terrane ...

\section{Tables}

Table 1. U-Pb analytical data for igneous zircons from sample 96AD8F. 



\title{
U-Pb Geochronology and Tectonic Implications of a Silurian Ash in the Farewell Terrane, Alaska
}

\author{
By Dwight C. Bradley, Julie A. Dumoulin, and Dan B. Bradley
}

\section{Abstract}

The Farewell terrane is an exotic continental fragment in interior Alaska that during the early Paleozoic was the site of a passive margin. We report a ${ }^{238} \mathrm{U} / 206 \mathrm{~Pb}$ zircon age of 432.9 3.0 Ma from a Farewell terrane ash in Mt. McKinley quadrangle, Alaska. This age overlaps with prominent detrital zircon age maxima reported from Silurian and Devonian strata from the Farewell, Arctic Alaska-Chukotka, White Mountains, Alexander, and Yreka terranes, and from parautochtonous Silurian and Devonian foreland-basin strata along the Laurentian margin in the Canadian Arctic and Alaska. These findings can be explained in terms of refinements to the extrusion model of Colpron and Nelson (2011). In the original model, the Farewell terrane was interpreted as having been extruded westward into the paleo-Pacific realm from an initial position along the Siberian margin of the Uralian seaway, that is, the early Paleozoic ocean between Siberia and Baltica. We suggest (1) that the Farewell terrane was deposited along a passive margin that faced into the Uralian seaway; (2) that the terrane more likely originated along the northern or eastern margin of Baltica (present directions), rather than Siberia; and (3) that the Silurian ash and Silurian detrital zircons were derived from a magmatic source along a convergent margin that overrode distal parts of the Farewell passive margin during the Late Ordovician and Silurian. The Farewell terrane was eventually dislodged from Baltica, began to travel with the extruding plate, and was conveyed toward the Pacific to its eventual resting place in Alaska.

\section{Introduction}

The Farewell terrane is an exotic continental fragment in the western interior of Alaska (fig. 1). Its hallmark is a late Neoproterozoic to early Paleozoic continental margin, which includes a distal, deep-water succession, the Dillinger subterrane of Bundtzen and others (1997). During geologic investigations in the 1990s, ash layers were found interbedded with turbidites in the Dillinger succession in the McGrath 1:250,000 quadrangle, and in correlative strata in the Mt. McKinley 1:250,000 quadrangle (Bundtzen and others, 1997; Dumoulin and others, 1998a) (fig. 2). These ashes are important to the regional tectonic evolution because they provide evidence for early Paleozoic volcanism on or near the Farewell terrane, and thus suggest that the continental margin was not a typical Atlantic-type, passive margin at that time. When Dumoulin and others (1998a) published their report, no geochronological data were available for the ashes in the Mt. McKinley quadrangle, although a Silurian age was inferred from indirect fossil evidence. Here we present $\mathrm{U}-\mathrm{Pb}$ zircon data that confirm and refine the Silurian age, and explore the tectonic implications for evolution of the Farewell terrane.

\section{Geologic Setting}

Most of Alaska is a collage of continental fragments, magmatic arcs, and deformed sedimentary basins, which were assembled in stages through much of the Phanerozoic and continue to be reshuffled along active strike-slip faults. Figure 1 shows the outline of the Farewell terrane and various other terranes that are mentioned or discussed below: the Arctic Alaska-Chukotka, Kilbuck, White Mountains, Livengood, and Alexander terranes. What has long been referred to as the Arctic Alaska-Chukotka terrane (Moore and others, 1994) consists of Jurassic and older rocks of the Brooks Range orogen that predate the Brookian orogeny. The North Slope subterrane of the Arctic Alaska terrane is now regarded as a separate, formerly independent block of Laurentian origin (Strauss and others, 2013; Lane and others, 2016), which prior to Brookian orogenesis should be considered separately from the rest of the Arctic Alaska terrane. Arc rocks in the core of the Doonerak window (fig. 1) also appear to belong to still another separate block (Strauss and others, 2017).

Rocks of the Farewell terrane are exposed across an area about the size of Switzerland. Its components, whose relations are summarized in figure 3, are: (1) the Nixon Fork subterrane, a late Neoproterozoic to Devonian platformal succession that overlies an older Neoproterozoic basement complex; (2) the Dillinger subterrane, which ranges from Cambrian to Devonian and is the deep-water equivalent of the Nixon Fork platform; and (3) the Mystic subterrane, a Devonian to Cretaceous mixed succession of carbonate, siliciclastic, and mafic volcanic rocks, which overlaps both the Nixon Fork and Dillinger. These subterranes were formerly classified as separate terranes (Jones and others, 1987; Silberling and others, 1994; Patton and others, 1994) but were later grouped into a single entity, 


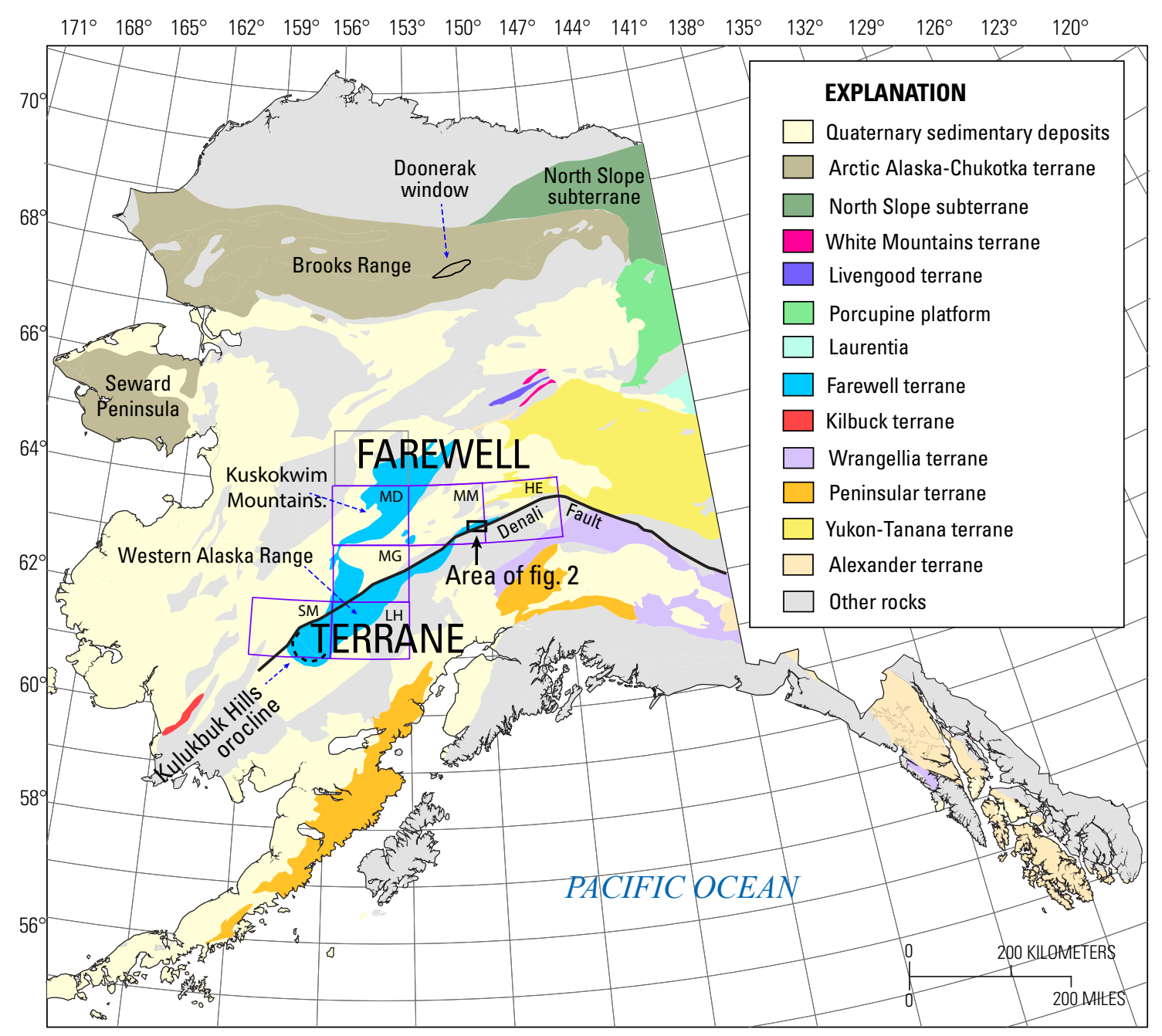

Figure 1. Generalized tectonic map of Alaska showing the Farewell terrane and selected other terranes. Abbreviations for 1:250,000 quadrangles: HE, Healy; MD, Medfra; MG, McGrath; MM, Mount McKinley. Adapted from Silberling and others (1994).

the Farewell terrane, on the basis of shared history (Decker and others, 1994). The main outcrop areas of the Farewell terrane are in the Kuskokwim Mountains and the western Alaska Range (fig. 1). The terrane is cut by the Denali Fault, a crustal-scale structure that is responsible for about $133 \mathrm{~km}$ of dextral map separation of Farewell rocks (Miller and others, 2002).

In the McGrath quadrangle where it is best exposed and most thoroughly documented, the Dillinger subterrane consists of (1) the Cambrian-Lower Ordovician Lyman Hills Formation, dominantly deep-water limestone; (2) the Ordovician-Silurian Post River Formation, mainly black shale, argillite, and lesser chert and limestone; (3) the Silurian Terra Cotta Mountains Sandstone, dominantly turbidites; and (4) the Devonian Barren Ridge Limestone, deep-water carbonate rocks (Churkin and Carter, 1996; Bundtzen and others, 1997).

The area of the present study is within a fault-bounded tract of sedimentary and low-grade metasedimentary rocks far to the east in the central Alaska Range in the Mt. McKinley and Healy quadrangles (figs. 1 and 2). These strata were mapped in reconnaissance by Csejtey and others $(1992,1996)$ as "unit DOs," that is, Devonian to Ordovician sedimentary rocks. Csejtey and others (1996) and Dumoulin and others (1998a) correlated various rocks within unit DOs with strata of the Dillinger and Mystic subterranes, making them the most easterly belt of rocks assigned to the Farewell terrane. Dumoulin and others (1998a) described the sedimentology and structure of unit DOs in detail at selected localities (fig. 2) and noted likely equivalents of the Lyman Hills Formation, Post River Formation, and Terra Cotta Mountains Sandstone.

Dumoulin and others (1998a) found ash and tuffaceous beds at six localities in Mt. McKinley quadrangle (locs. 1, 6, $8,9,10$, and 15 in fig. 2). Ashes at two of the localities are interbedded with variably calcareous siliciclastic turbidites of what was informally referred to as "subunit B," a proposed correlative of the Terra Cotta Mountains Sandstone (Dumoulin and others, 1998a). A gently folded, 8-10-m-thick section at location 9 (fig. 2) consists chiefly of thin-bedded, parallelto cross-laminated, calcareous radiolarite with subordinate 


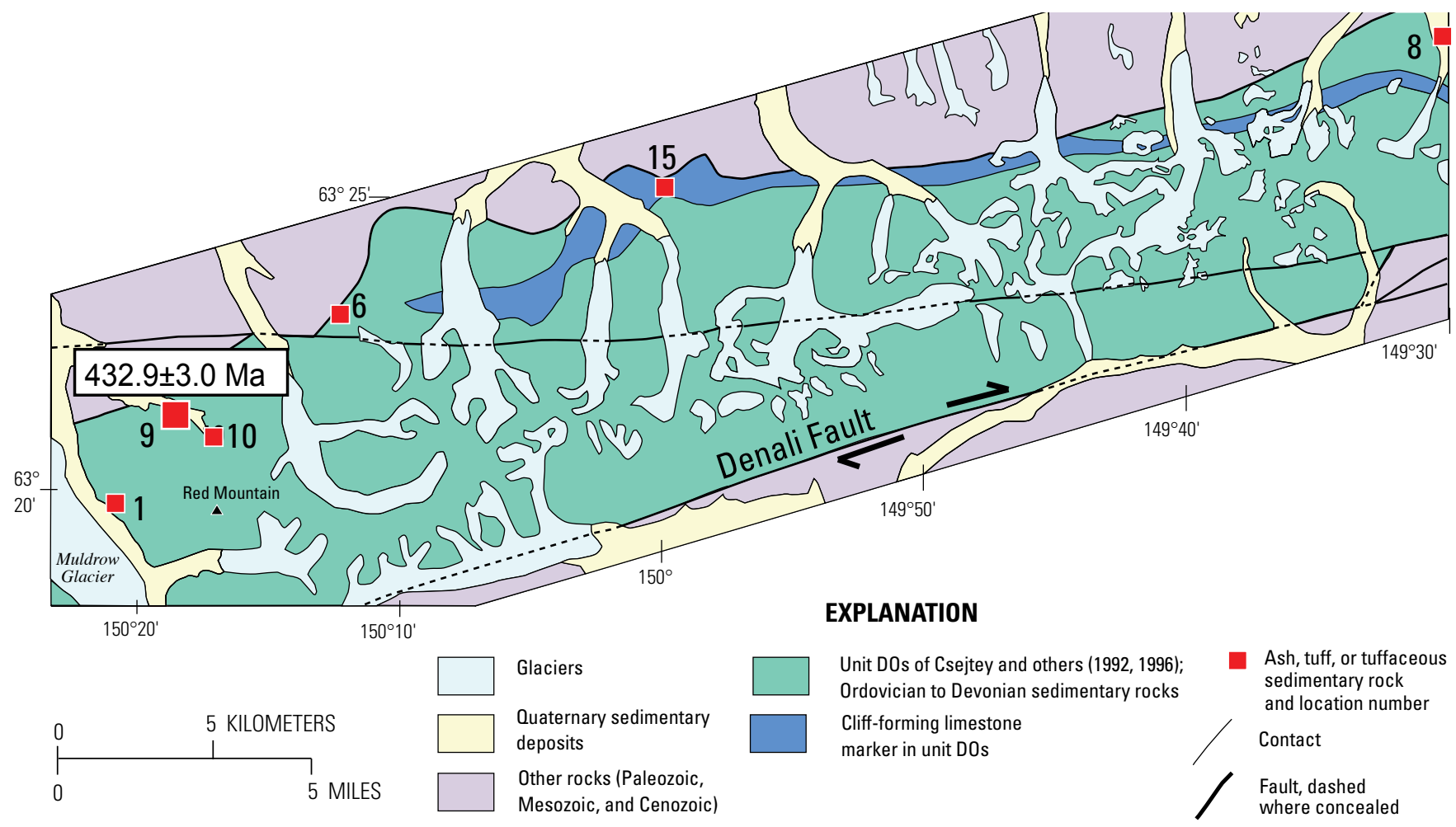

Figure 2. Geologic map of part of the Mount McKinley quadrangle, Alaska, from Dumoulin and others (1998a). Location numbers are the same as those used in Dumoulin and others (1998a).

interbeds ( $0.5-1.4 \mathrm{~m}$ thick) of very fine to medium-grained, calcareous graywacke turbidites. A detailed measured section of the basal $1.65 \mathrm{~m}$ of this exposure (fig. 4) encompasses at least 12 discrete ash layers that range in thickness from a few millimeters to $2 \mathrm{~cm}$, in color from white to yellow to gray to reddish brown, and in texture from friable to pasty to indurated.

The dated layer $-1.1 \mathrm{~m}$ above the base of the measured section-is $2 \mathrm{~cm}$ thick, light gray, and indurated. A 10-cm-thick bed of parallel- to cross-laminated calcareous radiolarite $0.5 \mathrm{~m}$ below the dated ash produced a conodont fauna of probable Silurian (Wenlock or younger) age (Dumoulin and others, 1998a). Thin sections from this bed and a similar bed near the base of the section contained whitish ash lenses and layers, 4 to $7 \mathrm{~mm}$ thick, that are rich in silt- to sand-sized euhedral to subhedral grains of feldspar and quartz.

\section{U-Pb Geochronology}

Zircon grains were separated from samples of four different ash layers at location 9 (field number 96AD8; coordinates $63.3550^{\circ} \mathrm{N}, 150.3106^{\circ} \mathrm{W}$ ). The ash samples were remarkably soft and pliable, presumably owing to surface weathering. The mineral separation took fewer steps and was faster than usual because the samples could be disaggregated using a kitchen blender and then poured directly onto a Wilfley table. Sample 96AD8F was selected for geochronology. The zircons from this ash layer are relatively abundant, clear, euhedral, stubby, and show pronounced oscillatory zoning of inferred igneous origin (fig. 5). U-Pb data were obtained using the SHRIMPRG (sensitive high-resolution ion microprobe, reverse geometry) at Stanford University, a joint facility of the U.S. Geological Survey and Stanford. Analytical methods are the same as those described by Bradley and others (2014).

Fourteen zircons were analyzed. Analytical data are given in table 1 and ${ }^{238} \mathrm{U} /{ }^{206} \mathrm{~Pb}$ results are summarized in figure 6 . A weighted average ${ }^{238} \mathrm{U} /{ }^{206} \mathrm{~Pb}$ age of $432.9 \pm 3.0 \mathrm{Ma}$ is obtained from a coherent cluster of eight ages. $\mathrm{Six}^{238} \mathrm{U} /{ }^{206} \mathrm{~Pb}$ ages were discounted, three younger ones for suspected lead loss and three older ones for suspected inheritance.

\begin{tabular}{|c|c|}
\hline \multicolumn{2}{|c|}{$\begin{array}{c}\text { Mystic subterrane } \\
\text { Devonian to Cretaceous } \\
\text { sedimentary and volcanic rocks }\end{array}$} \\
\hline $\begin{array}{c}\text { Nixon Fork subterrane } \\
\text { Neoproterozoic to Devonian } \\
\text { carbonate platform }\end{array}$ & $\begin{array}{l}\text { Dillinger subterrane } \\
\qquad 433-\text { Ma ash } * * * * * * * \\
\text { Cambrian to Devonian } \\
\text { deep-water basin }\end{array}$ \\
\hline $\begin{array}{l}\text { Continental basement } \\
\text { Neoproterozoic (and older?) }\end{array}$ & $\begin{array}{l}\text { Unknown } \\
\text { basement }\end{array}$ \\
\hline
\end{tabular}

Figure 3. Farewell subterrane nomenclature showing approximate position of the dated Silurian ash. 




\section{Discussion}

\section{Passive Margin Evolution}

Multiple lines of evidence suggest a passive-margin setting for the Nixon Fork-Dillinger subterrane pair during the early Paleozoic (Bradley, 2008). (1) Platformal facies of the Nixon Fork subterrane depositionally overlie Proterozoic continental basement, ruling out the alternative that the platform was built on an oceanic plateau like the Bahamas. (2) Detrital zircon populations from Neoproterozoic strata of the Nixon Fork subterrane (Bradley and others, 2014; Dumoulin and others, 2018) include abundant Paleoproterozoic zircons, indicating derivation from ancient continental sources, further ruling out an oceanic plateau origin. (3) Platformal facies interfinger with deeper water equivalents of the Dillinger subterrane (Decker and others, 1994), with deeper-water deposition generally toward the east. This is consistent with a shelf to slope to rise arrangement of facies characteristic of modern passive margins. (4) A subsidence curve from the Nixon Fork platform shows an exponential form (Dumoulin and others, 1998b), consistent with thermal subsidence from about 480 to about $435 \mathrm{Ma}$, that is, Early Ordovician to early Silurian.

Both components of the inferred passive margin - the Nixon Fork and Dillinger subterranes - underwent tectonically significant changes in the Late Ordovician and Silurian. In the Nixon Fork succession in the Medfra 1:250,000-scale quadrangle, deep-water carbonates and shales in the upper part of the Telsitna Formation record platform drowning during Late Ordovician time; deep-water conditions continued through the Silurian with deposition of the Paradise Fork Formation. Farther

at location 9

(see fig. 2).
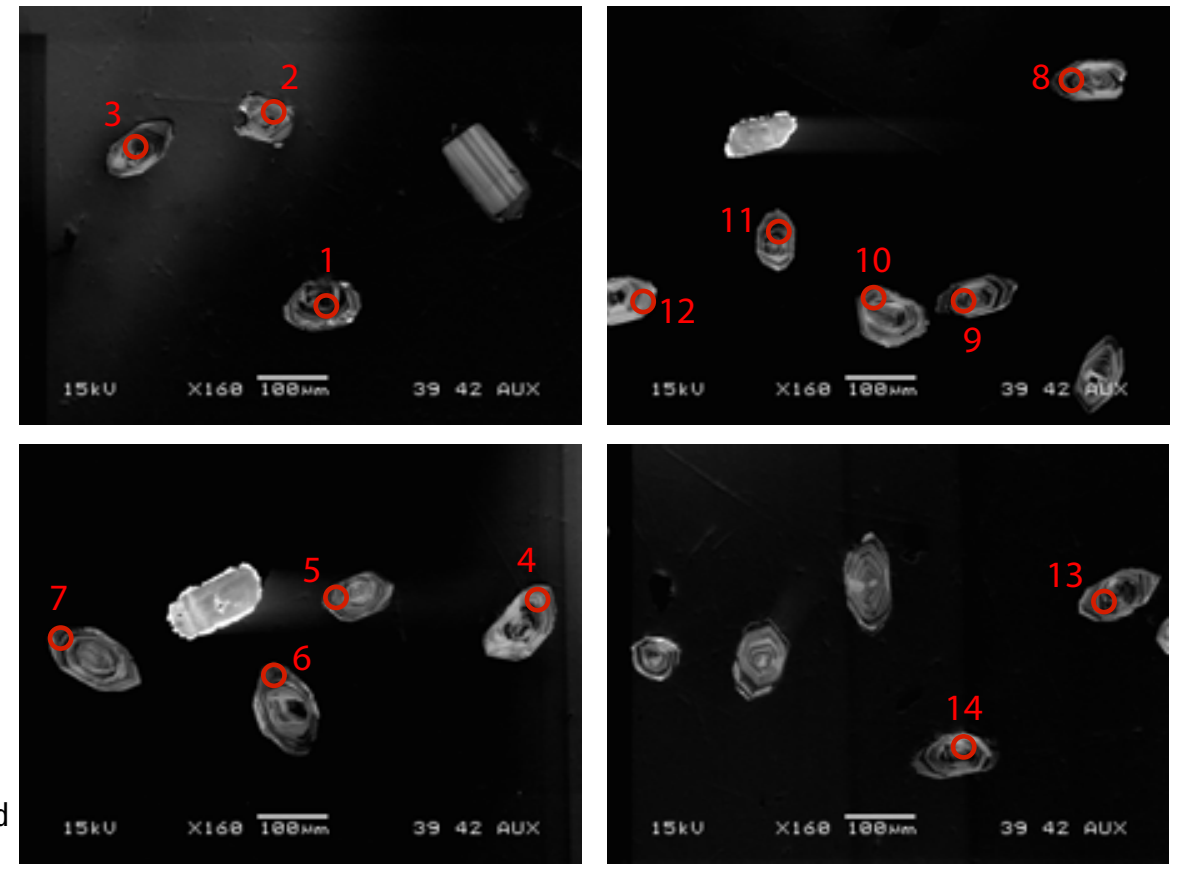

Figure 5. Cathodoluminescence images of the dated zircons from sample 96AD8F at location 9 (see fig. 2). Numbered circles are spots on zircons that were analyzed, as listed in the second column in table 1. 
south in the Nixon Fork subterrane, in the McGrath, Lime Hills, and Sleetmute 1:250,000-scale quadrangles, the Nixon Fork succession includes a distinctive, 100-km-long Silurian algal reef complex that developed along the platform edge (Clough and Blodgett, 1988).

The Dillinger succession began to receive young detrital zircons in the Ordovician. In McGrath quadrangle, a quartz-rich, deep-water sandstone from the Ordovician Post River Formation yielded a major population of latest Cambrian-earliest Ordovician (about $490 \mathrm{Ma}$ ) grains from what appears to have been a new, non-Farewell source (Dumoulin and others, 2018). Turbidites of the Terra Cotta Mountains Sandstone that were deposited at about the time of the Llandovery-Wenlock boundary included a major population of Silurian zircons that also were derived from a non-Farewell source (Dumoulin and others, 2018). The dated ash from unit DOs is roughly coeval with the influx of turbidites of the Terra Cotta Mountains Sandstone.

In the present reference frame, the passive margin faced generally east. This is inferred from the relative positions of the Nixon Fork shallower-water deposits and Dillinger deeper-water deposits. A more precise facing direction cannot be specified because the Farewell terrane bends around a tight oroclinal flexure at its southwestern end, the Kulukbuk Hills orocline of Johnston (2001) (fig. 1). Paleomagnetic data from Ordovician Nixon Fork strata in Medfra quadrangle suggest that the western limb of the orocline has undergone an approximately $78^{\circ}$ clockwise net rotation (Plumley, 1984). The age of inferred oroclinal bending is not well known, but regardless, this sector of the Farewell passive margin is inferred to have originally faced approximately north.

\section{Potential Sources of the $433-$ Ma Ash}

At 432.9 $\pm 3.0 \mathrm{Ma}$, the Farewell terrane must have been sufficiently close to a volcanic center for water-lain ash to have been interlayered with the ambient deep-water sediments. As there are no documented Silurian plutonic or volcanic rocks in the Farewell terrane, an external source for the ash is most likely. Because paleogeographic elements in the circum-Arctic and North American Cordillera have been severely disrupted, the Farewell terrane may or may not presently be close to its Silurian neighbors.

First we discuss possible sources of the ash in various Alaskan terranes. Most prominent of these is the Alexander terrane of southeastern Alaska and adjacent Canada, the site of arc magmatism from Early Ordovician to early Silurian time (Nelson and others, 2013). Gehrels and Saleeby (1987) reported $\mathrm{U}-\mathrm{Pb}$ ages of $438 \pm 5,438 \pm 5$, and $438 \pm 4$ Ma from three granitic plutons in the Alexander terrane on Prince of Wales Island, southeastern Alaska (fig. 1). The Ordovician to lower Silurian Descon Formation of the Alexander terrane on Prince of Wales Island consists largely of mafic to intermediate volcanic rocks, plus subordinate argillite, mudstone, siltstone, and graywacke, and minor limestone (Gehrels and Saleeby, 1987). A volcanic breccia horizon in the Descon Formation yielded an ${ }^{40} \mathrm{Ar} /{ }^{39} \mathrm{Ar}$ hornblende plateau age of $436.2 \pm 5.0 \mathrm{Ma}$ (Kunk and others, 1985). Graptolites in shale from just below the dated horizon are early Silurian (early Llandovery) in age (Kunk and others, 1985).



Figure 6. Plot showing ${ }^{238} \mathrm{U} / 206 \mathrm{~Pb}$ zircon age results for sample 96AD8F. The ages of individual zircons are shown by vertical black and light gray bars; height and position of each bar corresponds to age \pm 2 -sigma uncertainty. Analyses represented by vertical black bars were used to calculate the weighted average ${ }^{238} \mathrm{U} / 206 \mathrm{~Pb}$ zircon age of $432.9 \pm 3.0 \mathrm{Ma}$ (mean square weighted deviation=1.5, probability $=0.16$ ). Analyses represented by vertical gray bars were not included in the weighted average calculation. The heavy red line represents the weighted average ${ }^{238} \mathrm{U} / 206 \mathrm{~Pb}$ age of the ash sample; the wider pink band represents the corresponding 2-sigma uncertainty. Analytical data are given in table 1. 


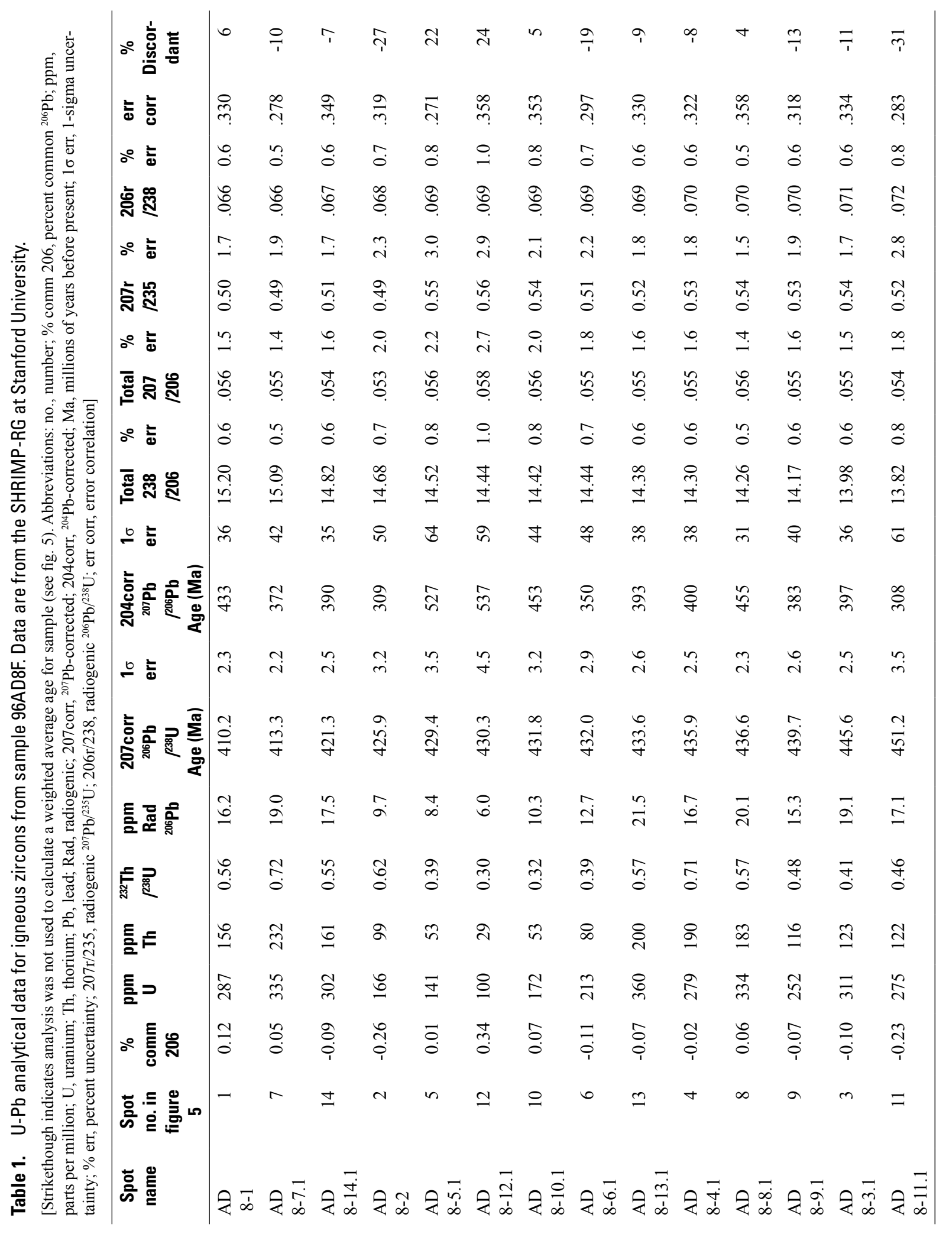


Another possible igneous source is the White Mountains terrane in the Livengood 1:250,000 quadrangle, central Alaska (fig. 1). The Fossil Creek Volcanics consist largely of volcanic rocks (alkali basalt and agglomerate), plus subordinate sedimentary rocks including volcaniclastic conglomerate, limestone, and sandstone (Weber and others, 1992). The Fossil Creek succession has long been assigned an Ordovician age based on Tremadocian and Ashgillian fossils, an age range that is further supported by an early Silurian (early Llandovery) fossil age from the overlying Tolovana Limestone (see summary in Dumoulin and others, 2018). New detrital zircon results from two volcaniclastic rocks in the uppermost few meters of the Fossil Creek Volcanics show that the top of the Fossil Creek is younger than previously thought. Both zircon age spectra show single maxima, at $438 \pm 5$ and $436 \pm 5 \mathrm{Ma}$ (Dumoulin and others, 2018), implying maximum depositional ages in the early Silurian. Although more information is needed, the available data thus allow the possibility that the dated ash in the Farewell terrane came from an igneous source in the White Mountains terrane.

A third conceivable Alaskan source is the recently documented Apoon assemblage in the Doonerak window of the central Brooks Range (Strauss and others, 2017). These arc rocks range in age from Cambrian to Devonian, a span that encompasses the age of the Silurian ash from the Farewell terrane. Silurian igneous ages have yet to be obtained from Doonerak, however. On this fragmentary evidence, the Apoon arc can be regarded as a permissible source for the Farewell ash.

Another potential source region, now thousands of kilometers away, is the northern Caledonide orogen, which formed during convergence and then collision between Baltica and Laurentia (Corfu and Hartz, 2011). The Ordovician and Silurian cover succession of the Baltic craton contains abundant ash layers, including 60 ashes from the Telychian stage of the late Llandovery (which ranges in age from 438.5 to $433.4 \mathrm{Ma}$ ), and 49 ashes from the Sherwoodian stage of the early Wenlock (which ranges in age from 433.3-430.5 Ma) Kiipli and others, 2013). The ashes of this age range have been interpreted as having come from the Norwegian Caledonides (Kiipli and others, 2013). A rationale for entertaining the Caledonide orogen as a possible source of the Farewell ash is discussed in the section "Implications for Plate Reconstructions."

\section{Age Overlap Between the Dated Ash and a Widespread Detrital-Zircon Age Maximum}

Many detrital zircon samples from Alaska and adjacent regions show pronounced population peaks in the Silurian, which are coeval or nearly coeval with the dated ash. The samples fall into four categories: (1) those from exotic terranes with no known Silurian magmatism - the Farewell, Arctic Alaska, and Yreka (California); (2) those from exotic terranes with known or inferred Silurian magmatism - the White
Mountains and Alexander; (3) those from parautochthonous Laurentian-margin successions - in east-central Alaska and Ellesmere Island, Canada; and (4) those from the Appalachian orogen, on the other side of Laurentia, deemed too distant to have direct, simple ties to the Farewell terrane, although they are parts of the same hemispheric-scale orogenic system (Bradley and O'Sullivan, 2016).

Most directly relevant to the present discussion is the Terra Cotta Mountains Sandstone itself. Five detrital zircon samples from the Terra Cotta all have similar age distributions, with prominent Silurian age peaks from 430 to $423 \mathrm{Ma}$ and a broad, lower amplitude Mesoproterozoic population (Dumoulin and others, 2018). In one of the five samples (11SB110A), the Silurian peak is at $430 \pm 5 \mathrm{Ma}$ (Dumoulin and others, 2018) (fig. 7A), which overlaps with both the fossil-based age of the Terra Cotta Mountains Sandstone and the age of the dated ash in unit DOs. A straightforward interpretation is these detrital zircons came from the same magmatic belt as the ash beds that were deposited with the ambient deep-water sedimentary rocks of the Farewell terrane.

Similar detrital zircon age spectra from various other terranes are shown in Figure $7 B-D$. All have prominent Silurian age peaks and a broad, lower amplitude Mesoproterozoic population. In a composite plot of metasedimentary samples from the Devonian part of the Nome Complex of the Arctic Alaska terrane of the Seward Peninsula (figs. 1 and 8), the Silurian peak is at $438 \mathrm{Ma}$ (Till and others, 2014) (fig. 7B). In the Devonian Karheen Formation of the Alexander terrane in southeastern Alaska (figs. 1 and 8), the corresponding age peak is at $431 \mathrm{Ma}$ (Gehrels and others, 1996) (fig. 7C). In the Yreka terrane of the Klamath Range, California (fig. 8), in the Devonian Duzel Phyllite, the prominent Silurian age peak is listed, with low precision, at about $420 \mathrm{Ma}$ (Grove and others, 2008) (fig. 7D). Silurian and Devonian strata from at least two widely spaced locations along the Laurentian margin also show a prominent Silurian detrital zircon age maximum. The Devonian Nation River Formation of east-central Alaska (fig. 8) shows a major zircon age peak at $431 \mathrm{Ma}$ (Gehrels and others, 1999) (fig. 7E). Late Silurian (Pridoli) sandstones of Ellesmere Island, Arctic Canada (fig. 8), show partly overlapping age peaks at 424 and $447 \mathrm{Ma}$ (Beranek and others, 2015) (fig. 7F). As far away as the Acadian collisional suture in Maine (fig. 8), Bradley and O'Sullivan (2016) reported a composite plot of $>600$ detrital zircon ages from uppermost Ordovician to lowermost Devonian siliciclastic rocks, with a relatively prominent age peak at 437 Ma and a much broader but lower amplitude Mesoproterozoic age group (fig. $7 G$ ).

\section{Implications for Plate Reconstructions}

The Farewell terrane was receiving ash at $432.9 \pm 3.0 \mathrm{Ma}$ from a non-Farewell terrane source. Detrital zircons of this general age, also from non-Farewell sources, were deposited as part of the sedimentary cover of the Farewell terrane at about this time. Bradley (2008, supplement) suggested that the 
influx of Silurian turbidites, the Silurian ash, and the Silurian deepening event all took place in an overall environment of tectonic loading, when the leading edge of the Farewell terrane was partly subducted beneath an encroaching arc. If such a collision did take place, the deformation front must have lain outboard (that is, in the direction the passive margin faced) of the presently exposed part of the Nixon Fork platform, which escaped severe deformation.

The broader context of these events remains speculative. During the first two decades following publication of the terrane model for the North American Cordillera (Coney

A. Terra Cotta Mountains Sandstone, Farewell terrane, Silurian
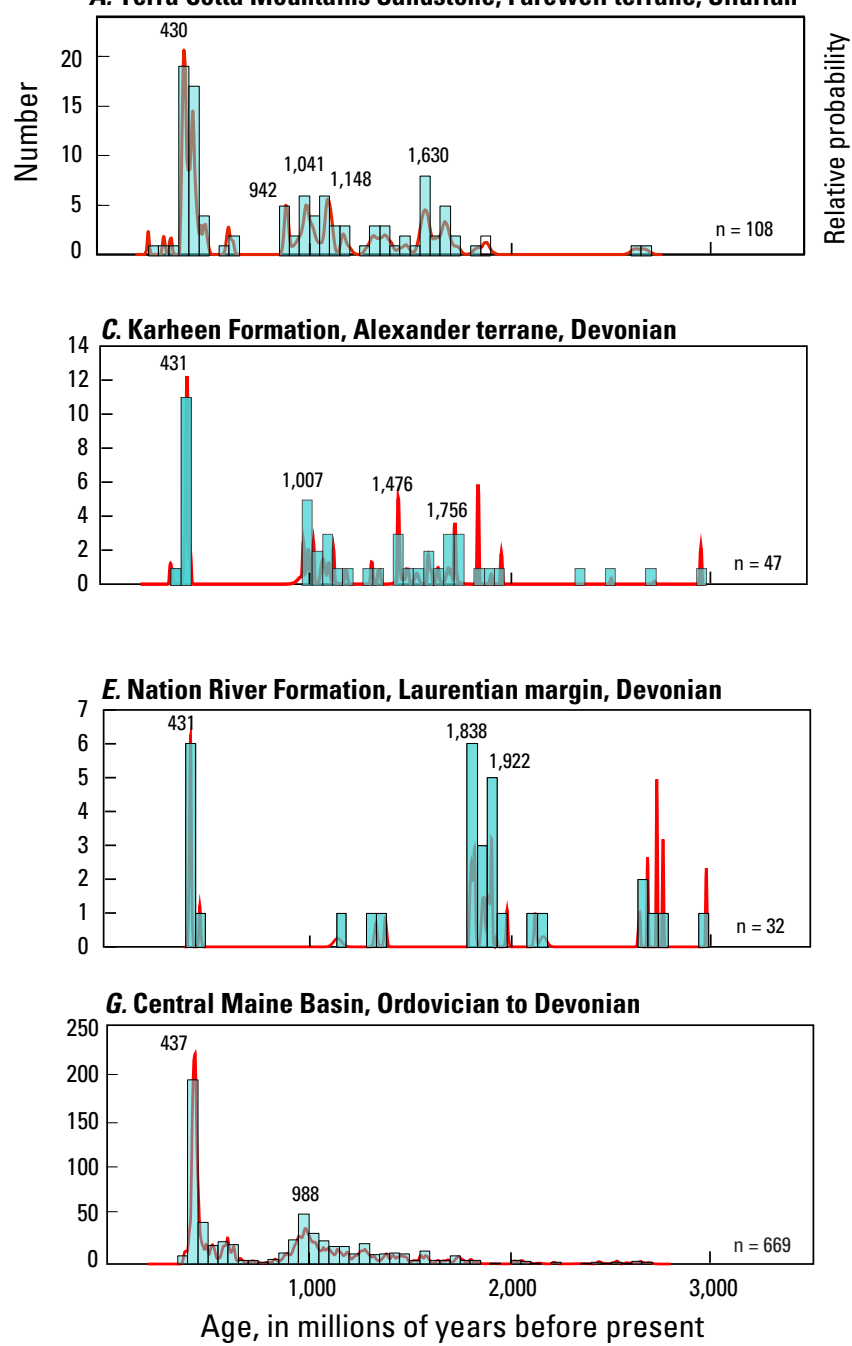

and others, 1980), the Nixon Fork platform was regarded as a displaced block of North American origin (Plafker and Berg, 1994) that had been translated northward along the continental margin. This idea was later abandoned in light of fossil evidence suggesting closer proximity to Siberia than to Laurentia (Dumoulin and others, 2002; Blodgett and others, 2002). More recently, detrital zircon data were interpreted to suggest that the Arctic Alaska and Farewell terranes originated along the northern or eastern margin of Baltica (Amato and others, 2009; Till and others, 2014; Dumoulin and others, 2018). Because Baltica and Siberia were separated during the Ordovician and Silurian by a relatively narrow ocean basin
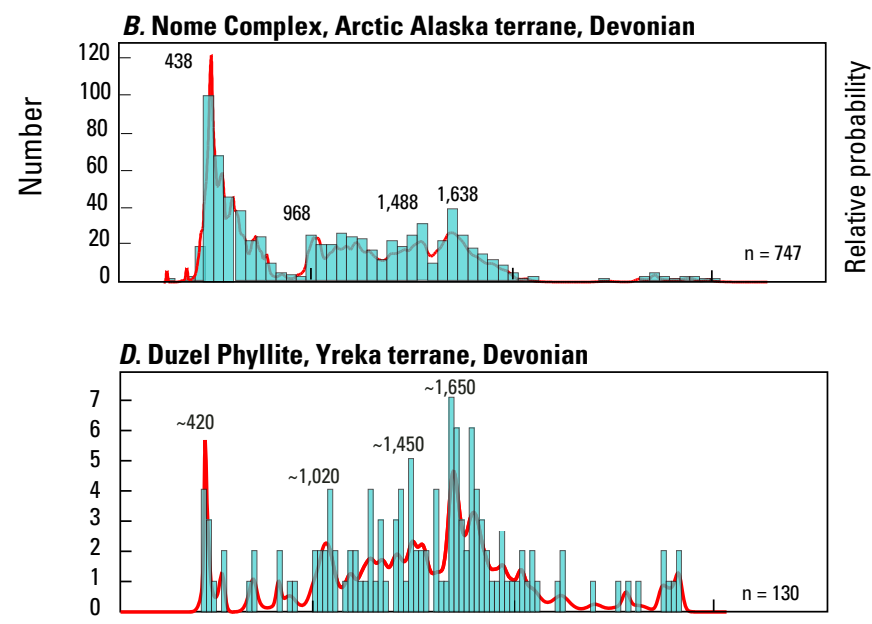

Figure 7. Detrital zircon age distributions for Silurian and Devonian rock units in western, northern, and eastern North America that have prominent age peaks at 440-420 Ma. Data shown in two ways, as histograms of number of zircon ages per bin (blue rectangles have durations of 50 m.y.) and as probability density curves (red line). In each plot, $\mathrm{n}$ is number of zircon ages. $A$, Terra Cotta Mountains Sandstone (sample 11SB110a), from Dumoulin and others (2018). B, Nome Complex (composite of nine samples), Arctic Alaska terrane, Seward Peninsula, from Till and others (2014). C, Karheen Formation, Alexander terrane, southeastern Alaska, from Gehrels and others (1996). D, Duzel Phyllite (composite of six samples), Yreka terrane, California, from Grove and others (2008). E, Nation River Formation, east-central Alaska, from Gehrels and others (1999). F, Lands Lokk and Danish River Formations (composite of three samples), Silurian (Pridoli), Canadian Arctic, from Beranek and others (2015). G, Late Ordovician to Early Devonian rocks from the Central Maine Basin, Appalachian orogen (composite of eight samples), from Bradley and 0'Sullivan (2016). 


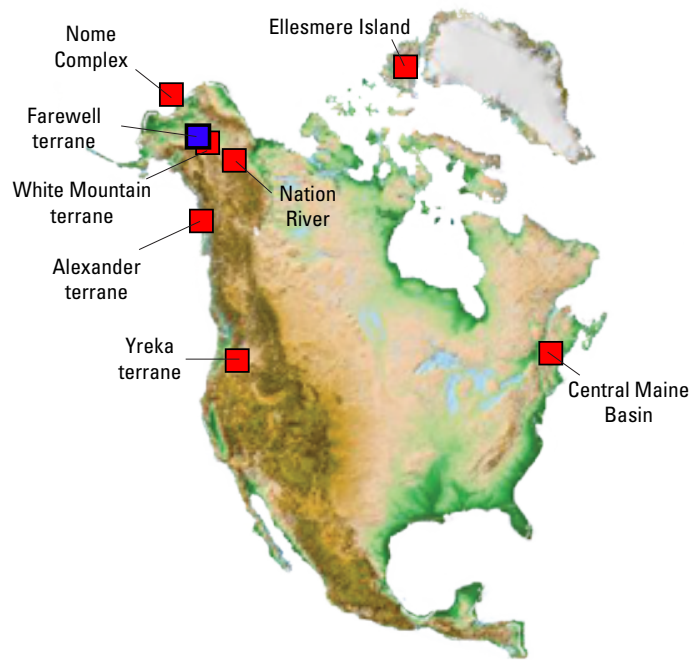

Figure 8. Map of North America showing locations of terranes and rock units mentioned in text and in figure 7.

(the Uralian seaway) (fig. 9), these two options are not too different. The Ordovician episode of thermal subsidence seen in the Nixon Fork succession, noted above, is broadly consistent with events along the Uralian (eastern) passive margin of Baltica, which formed in the Early Ordovician (see review in Bradley, 2008, supplement).

In a seminal model proposed by Colpron and Nelson $(2009,2011)$, the Farewell terrane was interpreted to be one of several continental fragments in the Cordillera that originated in the circum-Arctic and were extruded toward the ancestral Pacific realm. This model draws on a well-studied analog: the Mesozoic to Cenozoic west-to-east extrusion of the Caribbean plate through the gap between North and South America, from the Pacific into the Atlantic. The Caribbean plate has a subduction zone along its leading edge, and transform, transpressional, or transtensional boundaries along its flanks (Burke, 1988). Wright and Wyld (2006) proposed a similar tectonic model involving extrusion of terranes through a Paleozoic gap between Laurentia and the South American part of Gondwana. Waldron and others (2014) likewise proposed a model for extrusion of an arc through a Paleozoic Caledonide gap between Baltica and Gondwana.

The tectonic reconstruction in figure 9 shows the main elements of the Colpron and Nelson $(2009,2011)$ model for the Silurian as they pertain to the Farewell terrane. On one side of the Uralian seaway lay Siberia. On the other side lay Baltica and Laurentia. The latter two had just been sutured along the Caledonide orogen (Corfu and Hartz, 2011). Locations B (for Baltica) and S (for Siberia) show two possible positions of the Farewell terrane; these are meant to represent generalized locations somewhere along one or the other margin. The Baltica option is consistent with detrital zircon evidence (Amato and others, 2009; Till and others, 2014); the Siberian option is adapted from Antoshkina and Soja (2016), based on the distribution of Silurian algal reefs. We suggest that in either case, the extruding, Caribbean-like plate overrode the edge of the Farewell terrane passive margin at the time depicted in figure
9. Volcanic eruptions episodically blanketed parts of the terrane with ash. At the same time, Silurian and Mesoproterozoic detrital zircons were transported from exposed bedrock sources of those ages. The ashes might either have been erupted from an arc on the extruding plate (location E in fig. 9), or from the Caledonide orogen (location C). We currently lean toward what we regard as the simpler scenario, with the Farewell terrane at location $\mathrm{B}$ and the ashes and detrital zircons coming from location E. At the reconstructed low northern-hemisphere latitudes shown in figure 9, ash from a source at $E$ would have been blown by northeasterly trade winds toward B. In this respect, location $\mathrm{C}$ does not work as well as an ash source, nor does location S work as well for the Farewell terrane's position. As extrusion continued into Devonian time, Silurian detrital zircons were shed onto the Arctic Alaska-Chukotka and Yreka terranes at other unspecified locations along the Laurentia-Siberia gap, presumably closer to the paleo-Pacific Ocean. In the Devonian, at least two locations along the Laurentian margin (Canadian Arctic and east-central Alaska) (fig. 8) also received detritus that included abundant Silurian zircons. Eventually the upper plate grew to include some of the rocks (now terranes) that had originally lined the gap.

In summary, the events in the Farewell terrane highlighted above-Late Ordovician deepening of the passive margin, influx of Silurian turbidites bearing Silurian detrital zircons, and deposition of volcanic ash - can all be explained by Colpron and Nelson's $(2009,2011)$ tectonic model for circum-Arctic evolution, subject to refinements.



Figure 9. Schematic tectonic reconstruction at about $433 \mathrm{Ma}$ (approximately equivalent to the Llandovery-Wenlock boundary), modified from the extrusion model of Colpron and Nelson (2009, 2011) to better account for evidence from the Farewell terrane. Pink areas represent the generalized shapes and locations of the Silurian continents; for reference, gray lines show the corresponding modern shorelines. Two possible generalized positions are shown for the Farewell terrane, one along the margin of Baltica (location B), and one along the margin of Siberia (location S). Two possible sites are shown for the volcanic source of the dated ash: an arc on the extruding plate (green color), possibly the Alexander terrane (location E), or the Caledonide orogen (location C). Continued extrusion eventually brought the Farewell terrane to location A in present-day Alaska. Other terranes are not shown. 


\section{Acknowledgments}

This paper is based on fieldwork in Denali National Park in 1996 and follow-up geochronological studies in 2007, both supported by the U.S. Geological Survey's Mineral Resources Program. We are grateful to Alison Till for getting us started in Farewell terrane work. Coauthor Dan Bradley did the sample preparation, zircon imaging, and isotopic analysis as a U.S. Geological Survey volunteer, while in high school. Phil Breeze helped with access and logistics. We thank Joe Wooden, Frank Mazdab, and Brad Ito for guidance at the SHRIMP-RG facility at Stanford University. Technical reviewers Steve Box and Jamey Jones provided helpful comments that substantially improved the manuscript.

\section{References Cited}

Amato, J.M., Toro, J., Miller, E.L., Gehrels, G.E., Farmer, G.L., Gottlieb, E.S., and Till, A.B., 2009, Late ProterozoicPaleozoic evolution of the Arctic Alaska-Chukotka terrane based on U-Pb igneous and detrital zircon ages-Implications for Neoproterozoic paleogeographic reconstructions: Geological Society of America Bulletin, v. 121, p. 1219 1235, doi:10.1130/B26510.1.

Antoshkina, A.I., and Soja, C.M., 2016, Using fossil "fingerprints" to circumscribe the paleogeography of two Alaskan terranes along te Uralian Seaway in the Late Silurian: Vestnik, no. 2, p. 14-23, doi:10.19110/2221-1381-2016-2-14-23.

Beranek, L.P., Pease, V., Hadlari, T., and Dewing, K., 2015, Silurian flysch successions of Ellesmere Island, Arctic Canada, and their significance to northern Caledonian palaeogeography and tectonics: Journal of the Geological Society of London, v. 172, p. 201-212.

Blodgett, R.B., Rohr, D.M., and Boucot, A.J., 2002, Paleozoic linkages between some Alaskan accreted terranes and Siberia based on megafossils: Geologic Society of America Special Paper 360, p. 273-290.

Bradley, D.C., 2008, Passive margins through Earth history: Earth-Science Reviews, v. 91, p. 1-26 and supplementary data, doi:10.1016/j.earscirev.2008.08.001.

Bradley, D.C., McClelland, W.C., Friedman, R.M., O’Sullivan, P., Layer, P.W., Miller, M.L., Dumoulin, J.A., Till, A.B., Wooden, J.L., and Abbott, J.G., 2014, Proterozoic geochronological links between the Farewell, Kilbuck and Arctic Alaska Terranes: The Journal of Geology, v. 122, p. 237-258, doi:10.1086/675663.
Bradley, D.C., and O'Sullivan, P., 2016, Detrital zircon geochronology of pre- and syn-collisional strata, Acadian orogen, Maine Appalachians: Basin Research, v. 29, p. 571-590, doi:10.1111/bre.12188.

Bundtzen, T.K., Harris, E.E., and Gilbert, W.G., 1997, Geologic map of the eastern half of the McGrath quadrangle, Alaska: Alaska Division of Geological and Geophysical Surveys Report of Investigations 97-14a, 38 p., scale 1:125,000.

Burke, K., 1988, Tectonic evolution of the Caribbean: Annual Review of Earth and Planetary Sciences, v. 16, p. 201-230.

Churkin, M., Jr., and Carter, C., 1996, Stratigraphy, structure, and graptolites of an Ordovician and Silurian sequence in the Terra Cotta Mountains, Alaska Range, Alaska: U.S. Geological Survey Professional Paper 1555, 84 p.

Clough, J.G., and Blodgett, R.B., 1988, Silurian-Devonian algal reef mound complex of southwest Alaska, in Geldsetzer, H.H.J., James, N.P., and Tebbutt, G.E., eds., Reefs, Canada and adjacent area: Canadian Society of Petroleum Geologists Memoir 13, p. 404-407.

Colpron, M., and Nelson, J. L., 2009, A Paleozoic Northwest Passage - incursion of Caledonian, Baltican and Siberian terranes into eastern Panthalassa and the early evolution of the North American Cordillera: Geological Society of London Special Publication 318, p. 273-307, doi: 10.1144/SP318.

Colpron, M., and Nelson, J.L., 2011, A Palaeozoic NW Passage and the Timanian, Caledonian and Uralian connections of some exotic terranes in the North American Cordillera: Geological Society of London Memoir 35, p. 463-484, doi:10.1144/M35.31

Coney, P.J., Jones, D.L., and Monger, J.W.H., 1980, Cordilleran suspect terranes: Nature, v. 288, p. 329-333.

Corfu, F., and Hartz, E.H., 2011, U-Pb geochronology in Liverpool Land and Canning Land, East Greenland-The complex record of polyphase Caledonian orogeny: Canadian Journal of Earth Sciences, v. 48, p. 473-494, doi:10.1139/ E10-066.

Csejtey, B., Jr., Mullen, M.W., Cox, D.P., and Stricker G.D., 1992, Geology and geochronology of the Healy quadrangle, southcentral Alaska: U.S. Geological Survey Miscellaneous Investigations Series Map 1-1961, 63 p., 2 pls., scales $1: 250,000$ and $1: 360,000$.

Csejtey, B., Jr., Wrucke, C.T., Ford, A.B., Mullen, M.W., Dutro, J.T., Jr., Harris, A.G., and Brease, P.F., 1996, Correlation of rock sequences across the Denali fault in south-central Alaska: U.S. Geological Survey Bulletin 2152, p. 149-156. 
Decker, J., Bergman, S.C., Blodgett, R.B., Box, S.E., Bundtzen, T.K., Clough, J.G., Coonrad, W.L., Gilbert, W.G., Miller, M.L., Murphy, J.M., Robinson, M.S., and Wallace, W.K., 1994, Geology of southwestern Alaska, in Plafker, G., and Berg, H.C., eds., The geology of Alaska: Geological Society of America, Decade of North American Geology (DNAG), v. G-1, p. 285-310.

Dumoulin, J.A., Bradley, D.C., and Harris, A.G., 1998a, Sedimentology, conodonts, structure, and correlation of Silurian and Devonian metasedimentary rocks in Denali National Park, Alaska in Gray, J., and Riehle, J., eds., Geologic studies in Alaska by the U.S. Geological Survey in 1996: U.S. Geological Survey Professional Paper 1595, p. 71-98.

Dumoulin, J.A., Bradley, D.C., Harris, A.G., and Repetski, J.E., 1998b, Sedimentology, conodont biogeography, and subsidence history of the Nixon Fork terrane, Medfra quadrangle, Alaska [abs.]: Proceedings of the Third International Conference on Arctic Margins, Celle, Germany, p. 49.

Dumoulin, J.A., Harris, A.G., Gagiev, M., Bradley, D.C., and Repetski, J.E., 2002, Lithostratigraphic, conodont, and other faunal links between lower Paleozoic strata in northern and central Alaska and northeastern Russia: Geological Society of America Special Paper 360, p. 291-312.

Dumoulin, J.A., Jones, J.V., III, Bradley, D.C., Till, A.B., Box, S.E., and O'Sullivan, P., 2018, Neoproterozoic-early Paleozoic provenance evolution of sedimentary rocks in and adjacent to the Farewell terrane (interior Alaska): Geosphere, v. 14, no. 2, p. 1-28, doi:10.1130/GES01470.1.

Gehrels, G.E., Butler, R.F., and Bazard, D.R., 1996, Detrital zircon geochronology of the Alexander terrane, southeastern Alaska: Geological Society of America Bulletin, v. 108, p. 722-734.

Gehrels, G.E., Johnsson, M.J., and Howell, D.G., 1999, Detrital zircon geochronology of the Adams Argillite and Nation River Formation, east-central Alaska: Journal of Sedimentary Research, v. 69, p. 135-144.

Gehrels, G.E., and Saleeby, J.B., 1987, Geology of southern Prince of Wales Island, southeastern Alaska: Geological Society of America Bulletin, v. 98, p.123-137.

Grove, M., Gehrels, G.E., Cotkin, S.J., Wright, J.E., and Zou, $\mathrm{H}, 2008$, Non-Laurentian cratonal provenance of Late Ordovician eastern Klamath blueschists and a link to the Alexander terrane: Geological Society of America Special Paper 438, p. 223-250.

Johnston, S.T., 2001, The great Alaskan terrane wreck-reconciliation of paleomagnetic and geologic data in the northern cordillera: Earth and Planetary Science Letters, v. 193, p. 259-272.
Jones, D.L., Silberling, N.J. Coney, P.J., and Plafker, G.W., 1987, Lithotectonic terrane map of Alaska, west of the 141st Meridian: U.S. Geological Survey Map MF-1874-A, scale $1: 2,500,000$.

Kiipli, T., Kallaste, T., Kiipli, E., and Sigitas, R., 2013, Correlation of Silurian bentonites based on the immobile elements in the East Baltic and Scandinavia: GFF, v. 135, no. 2, p. 152-161, doi:10.1080/11035897.2013.783104.

Kunk, M.J., Sutter, J., Obradovich, J.D., and Lanphere, M.A., 1985, Age of biostratigraphic horizons within the Ordovician and Silurian system: Geological Society of London Memoir 10, p. 89-92.

Lane, L.S., Gehrels, G.E., and Layer, P.W., 2016, Provenance and paleogeography of the Neruokpuk Formation, northwest Laurentia-An integrated synthesis: Geological Society of America Bulletin, v. 128, p. 239-257.

Miller, M.L., Bradley, D.C., Bundtzen, T.K., and McClelland, W., 2002, Late Cretaceous through Cenozoic strike-slip tectonics of southwestern Alaska: Journal of Geology, v. 110, p. 247-270.

Moore, T.E., Wallace, W.K., Bird, K.J., Karl, S.M., Mull, C.G., and Dillon, J.T., 1994, Geology of northern Alaska, in Plafker, G., and Berg, H.C., eds., The geology of Alaska: Geological Society of America, Decade of North American Geology (DNAG), v. G-1, p. 49-140.

Nelson, J.L., Colpron, M., and Israel, S., 2013, The Cordillera of British Columbia, Yukon, and Alaska-Tectonics and metallogeny: Society of Economic Geologists Special Publication 17, p. 53-109.

Patton, W.W., Box, S.E., Moll-Stalcup, E.J., and Miller, T.P., 1994, Geology of west-central Alaska, in Plafker, G., and Berg, H.C., eds., The geology of Alaska: Geological Society of America, Decade of North American Geology (DNAG), v. G-1, p. 241-269.

Plafker, G., and Berg, H. C. 1994, Overview of the geology and tectonic evolution of Alaska, in Plafker, G., and Berg, H.C., eds., The geology of Alaska: Geological Society of America, Decade of North American Geology (DNAG), v. G-1, p. 989-1021.

Plumley, P.W., 1984, A paleomagnetic study of the Prince William terrane and Nixon Fork terrane, Alaska: Santa Cruz, University of California, Ph.D. thesis, 190 p.

Silberling, N.J., Jones, D.L., Monger, J.W.H., Coney, P.J., Berg, H.C., and Plafker, G., 1994, Lithotectonic terrane map of Alaska and adjacent parts of Canada, in Plafker, G., and Berg, H.C., eds., The geology of Alaska: Geological Society of America, Decade of North American Geology (DNAG), v. G-1, plate 3, scale 1:2,500,000. 
Strauss, J.V., MacDonald, F.A., Taylor, J.F., Repetski, J.E., and McClelland, W.C., 2013, Laurentian origin for the North Slope of Alaska-Implications for the tectonic evolution of the Arctic: Lithosphere, v. 5, p. 477-482, doi:10.1130 / L284.1.

Strauss, J.V., Hoiland, C.W., Ward, W.P., Johnson, B.G., Nelson, L.L., and McClelland, W.C., 2017, Orogen transplantTaconic-Caledonian arc magmatism in the central Brooks Range of Alaska: Geological Society of America Bulletin, v. 129, p. 649-676.

Till, A.B., Amato, J.M., Alenikoff, J.N., and Bleick, H.A., 2014, $\mathrm{U}-\mathrm{Pb}$ detrital zircon geochronology as evidence for the origin of the Nome Complex, northern Alaska, and implications for regional and trans-Arctic correlations: Geological Society of America Special Paper 506, p. 111-131.
Waldron, J.W., Schofield, D.I., Murphy, J.B., and Thomas, C.W., 2014, How was the Iapetus Ocean infected with subduction? Geology, v. 42, p. 1095-1098.

Weber, F.R., Wheeler, K.L., Rinehart, C.D., Chapman, R.M., and Blodgett, R.B., 1992, Geologic map of the Livengood quadrangle, Alaska: U.S. Geological Survey Open-File Report 92-562, 19 p., scale 1:250,000.

Wright, J.E., and Wyld, S.J., 2006, Gondwanan, Iapetan, Cordilleran interactions - A geodynamic model for the Paleozoic tectonic evolution of the North American Cordillera: Geological Association of Canada Special Paper 46, p. $377-408$. 
Menlo Park Publishing Service Center, California Manuscript approval date November 6, 2018

Edited by Claire Landowski

Design and layout by Kimber Petersen 
